\title{
Analisis Tingkat Hunian dari Persfektif Fasilitas Hotel di Nyiur Indah Beach Hotel Pangandaran
}

\author{
Dasril Indra* \\ Sekolah Tinggi Pariwisata Bandung, Indonesia \\ Email: dasrilindra@stp-bandung.ac.id
}

\begin{abstract}
This study aims to obtain empirical evidence about "Occupancy Rate Analysis of Effect Study Perspective Hotel amenities Hotel amenities Decision Against guest to stay at Nyiur Indah Beach Hotel Pangandaran". The results are expected to provide benefits of this research is to determine the extent of the facilities owned by Nyiur Indah Beach hotel guests can attract traffic and increase hotel revenue. The method used is descriptive analysis and 'verification. Data collection is an interview with using a questionnaire accompanied by literature study. The sampling technique used is the non-probability sampling techniques that do not provide equal opportunity for each element or member of the population to be sampled. Field data collection conducted in 2015. Data were analyzed using Path. Analysis (Path Analysis). The results showed that there are significant positive and significant effect of the variable to variable-making facility stay. Indicators rooms were clean and comfortable is important in influencing a person to stay. Basically the reason someone stay dihotel is to rest, the rooms are clean and comfortable will make a guest feel at home and comfortable in the rest.
\end{abstract}

Keywords: Hotel Facility, Purchase Decision.

\begin{abstract}
Abstrak
Pangandaran adalah tujuan wisata yang memiliki peran penting dalam pembangunan daerah pada tingkat nasional, regional dan lokal. Hal ini terbukti dari berbagai kebijakan, aturan, dan rencana yang ditetapkan dan diorganisasikan sebagai rujukan dalam pengembangan pariwisata Pangandaran ?: destinasi belum mampu meningkatkan daya saing kawasan. Pengembangan pariwisata di kawasan ini tidak hanya penting untuk sektor pariwisata itu sendiri tetapi lebih dari itu pengembangan pariwisata diharapkan dapat meningkatkan kesejahteraan masyarakat dan memperkuat posisi daerah sebagai suatu daerah dan prioritas dapat meningkatkan ekonomi daerah yang lebih luas. Pengembangan pariwisata, produk dan pasar pariwisata, Pangandaran terkenal di tingkat nasional dan internasional. Daya tarik pantai sebagai area produk utama adalah faktor penarik bagi wilayah ini. Namun, pengembangan produk wisata di kawasan ini masih belum terkelola dengan baik dan potensi dari pantai belum sepenuhnya dikembangkan sebagai pendukung daya tarik.

Kata Kunci: Pengembangan Pariwisata; Kebijakan Pariwisata; Tingkat Nasional dan Internasional; Produk dan Pasar Pariwisata..
\end{abstract}

\section{A. PENDAHULUAN}

Berdasarkan konteks keruangan nasional pada Rencana Tata Ruang Wilayah Nasional (RTRWN), dalam PP No. 47 Tahun 1997 tentang RTRWN, Kawasan Pangandaran dan sekitarnya merupakan salah satu kawasan andalan yang ada di Jawa Barat. Dalam Peraturan Gubernur Jawa Barat Nomor 48 Tahun 2006, tentang Rencana Induk Pengembangan Pariwisata Daerah (RIPPDA) Provinsi Jawa Barat, disebutkan bahwa Kawasan Rekreasi Pantai Pangandaran termasuk salah satu dari sembilan Kawasan

* Corresponding author 
Wisata Unggulan di Jawa Barat. Serta dalam Perda Jawa Barat No. 22 Tahun 2010 tentang RTRWP Jawa Barat tahun 2009-2029, kawasan Pangandaran ditetapkan sebagai kawasan stategis provinsi.

Pangandaran merupakan kabupaten di tenggara provinsi Jawa Barat yang memiliki berbagai potensi kepariwisataan. Beberapa objek wisata unggulan di kawasan ini sudah dikenal luas, bahkan hingga mancanegara, antara lain objek wisata Pantai Pangandaran, Cagar Alam Pananjung, Pantai Batu Hiu, Pantai Batu Karas, Pantai Madasari, Citumang, serta Cukang Taneuh atau yang lebih popular dengan sebutan Green Canyon. Objek-objek wisata tersebut selalu dibanjiri pengunjung tiap masa liburan datang.

Tingkat kunjungan wisatawan ke beberapa obyek wisata unggulan di Pangandaran dapat dilihat pada tabel berikut.

Tabel 1. Jumlah Pen gunjung Daya Tarik Wisata Unggulan Periode 20102014

\begin{tabular}{|r|r|r|r|r|r|r|r|c|}
\hline \multirow{2}{*}{ Tahun } & \multicolumn{2}{|c|}{ Pangandaran } & \multicolumn{2}{|c|}{ Batu Hiu } & \multicolumn{2}{|r|}{ Batu Karas } & \multicolumn{2}{|c|}{ Green Canyon } \\
\cline { 2 - 8 } & Jumlah & $\%$ & Jumlah & $\%$ & Jumlah & $\%$ & Jumlah & $\%$ \\
\hline 2010 & 470,450 & Na & 38,950 & Na & 46,421 & Na & 38,610 & Na \\
\hline 2011 & 590,004 & $\mathbf{1 1 . 2 7}$ & 46,481 & 8.82 & 55,043 & $\mathbf{8 . 5 0}$ & 58,685 & $\mathbf{2 0 . 6 3 \%}$ \\
\hline 2012 & 703,093 & $\mathbf{8 . 7 5}$ & 48,952 & 2.59 & 73,050 & $\mathbf{1 4 . 0 6}$ & 63,610 & $\mathbf{4 . 0 3}$ \\
\hline 2013 & 729,684 & $\mathbf{1 . 8 6}$ & 58,793 & $\mathbf{9 . 1 3}$ & 140,012 & $\mathbf{3 1 . 4 3}$ & 87,655 & $15.90 \%$ \\
\hline 2014 & 936,616 & 12.42 & 71,115 & 9.49 & 169,406 & 9.50 & 118,231 & $\mathbf{1 4 . 8 5 \%}$ \\
\hline
\end{tabular}

Sumber: Dispar Perindagkop Pangandaran, 2014.

Pada Tabel 1 dapat dilihat prosentase peningkatan juinlah pengunjung paling tinggi terdapat pada obyek wisata Batu Karas dan Green Canyon. Hal ini menunjukkan bahwa kedua obyek tersebut mulai dilirik para wisatawan sebagai destinasi wisata alternatif di Kawasan Wisata Rekreasi Pantai Pangandaran, selain Pantai Pangandaran sendiri yang memang sudah terkenal lebih dahulu dan lebih padat wisatawan. Dua obyekyang terletak di Kecamatan Cijulang (sekitar $30 \mathrm{~km}$ dari Pantai Pangandaran) itu memiliki daya tarik khas tersendiri. Pantai Batu Karas merupakan salah satu pantai surfing terbaik di Pulau Jawa dan ombaknya yang tidak terlalu besar cukup terkenal di kalangan para peselancar. Sedangkan Cukang Taneuh atau Green Canyon merupakan aliran dari sungai Cijulang yang melintas menembus gua yang penuh dengan keindahan pesona stalaktit dan stalakmitnya.

Sebagai kawasan andalan nasional dan kawasan wisata unggulan di Jawa Barat, kawasan Pangandaran dan sekitarnya disiapkan untuk dikembangkan sebagai tujuan wisata nasional dan internasional yang mempunyai daya saing dan berbasis masyarakat yang mampu mengoptimalkan sumber daya alam dengan menerapkan IPTEK untuk menjamin peningkatan kesejahteraan pelaku ekonomi dengan tanpa merusak lingkungan dan nilai-nilai budaya setempat. Upaya peningkatan pariwisata di kawasan Pangandaran lebih diintensifkan terutama mengenai kelengkapan sarana dan prasarananya.

Tabel 2. Jumlah Hotel, Kamar, dan Tamu Hotel di Daya Tarik Wisata Tahun 2014

\begin{tabular}{|r|r|r|r|c|}
\hline \multicolumn{2}{|c|}{ Kecamatan } & \multicolumn{2}{|c|}{ Pangandarar $>1$} & Total \\
\hline \multirow{3}{*}{ Jumlah Hotel } & ArTalnt & Qd & so \\
\cline { 2 - 5 } & Berbintang & 15 & 1 & $\mathbf{1 6}$ \\
\cline { 2 - 5 } & Fo & & 75 \\
\hline & Melati & 1,108 & 56 & $\mathbf{1 , 1 6 4}$ \\
\hline
\end{tabular}




\begin{tabular}{|c|r|c|r|r|}
\hline & Berbintang & 590 & 13 & $\mathbf{6 0 3}$ \\
\cline { 2 - 5 } Jumlah Kamar & Total & $\mathbf{1 , 6 9 8}$ & $\mathbf{6 9}$ & $\mathbf{1 , 7 6 7}$ \\
\hline \multirow{3}{*}{$\begin{array}{c}\text { Jumlah Tamu } \\
\text { Hotel. }\end{array}$} & Melati & 20,081 & 8,583 & $\mathbf{2 8 , 6 6 4}$ \\
\cline { 2 - 5 } & Berbintane & 13.494 & 1.080 & $\mathbf{1 4 . 5 7 4}$ \\
\hline Jumlah Pengunjung Obyek Wisa & 33,575 & 9,663 & 43,238 \\
\hline
\end{tabular}

Pada Tabel 2, terlihat bahwa penginapan dan fasilitas akomodasi yang lebih lengkap terkonsentrasi di Kecamatan Pangandaran sedangkan di Kecamatan Cijulang, dimana terdapat obyek-obyek wisata unggulan lain seperti Batu Karas dan Green Canyon, fasilitas penginapan atau hotel untuk mencukupi kebutuhan pengunjung yang ingin berlibur di kawasan tersebut juga perlu ditambah. Selain itu, mayoritas hotel yang ada di kawasan tersebut juga masih sekelas hotel melati.

Sebuah hotel pada umumnya mempunyai produk berupa fasilitas utama sebagai produk jasa yaitu kamar, ataupun fasilitas pendukung seperti kolam renang, restoran, laundry dan lain-lain. Fasilitas sendiri juga tidak bisa menjadi faktor penentu konsumen dalam menentukan pilihan untuk menginap pada sebuah hotel, namun lokasi juga menjadi pertimbangan penting dalam menentukan suatu lokasi, apakah lokasi tersebut dekat dengan pusat perbelanjaan, dekat dengan perkantoran atau lokasi yang cenderung tenang justru menjadi prioritas serta harga dapat dijadikan pemikat awal bagi konsumen terkait berapa mereka hams membayar.

Persaingan bisnis yang semakin modern menuntut transparansi dalam bersaing. Hal ini tentunya tidak lepas dari pihak internal untuk mempertahankan perusahaan agar tetap survive di jalurnya maka dilakukan penelitian untuk mengetahui faktor yang mempengaruhi seseorang untuk menginap di hotel. Dalam penelitian ini dipilih variabel fasilitas hotelsebagai fokus dari penelitian.

Dengan semakin berkembangnya kawasan wisata di daerah pangandaran dan semakin banyaknya kunjungan wisata pasca tsunami di Pangandaran, sudah seharusnya pelaku pariwisata di pangandaran dapat memberikan pelayanan yang baik terutama dari sisi akomodasinya yaitu dari sisi sarana dan prasarananya. Tentunya hal tersebut akan semakin memicu tingkat persaingan pelaku usaha pariwisata termasuk usaha perhotelan di daerah Pangandaran. Fasilitas adalah sarana yang sifatnya mempermudah konsumen untuk melakukan suatu aktifitas. Konsumen pada zaman sekarang adalah konsumen yang sangat kritis dalam membelanjakan uang mereka mcmpertimbangkan banyak faktor untuk memilih sebuah produk atau jasa termasuk jasa perhotelan. Fasilitas menjadi salah satu pertimbangan konsumen dalam menentukan pilihan. Pada tingkat yang hampir sama, semakin lengkap fasilitas yang disediakan hotel, maka akan semakin puas pelanggan dan akan tents memilih perusahaan tersebut sebagai pilihan prioritas. Berdasarkan uraian tersebut diatas, maka penulis tertarik untuk mengkaji secara mendalam dan memfokuskan penelitian pada: "Analisis Tingkat Pendapatan dari Persfektif Fasilitas Hotel studi Pengaruh Fasilitas Hotel Terhadap Keputusan Tamu untuk menginap di Nyiur Indah Beach Hotel Pangandaran".

Bertitik tolak dari latar belakang masalah tersebut maka yang menjadi pokok permasalahan yang akan dianalisa dan dibahas dalam penulisan ini apakah fasilitas hotel berpengaruh terhadap keputusan konsumen menginap sehingga meningkatkan pendapatan Nyiur Indah Beach Hotel Pangandaran. Berdasarkan pada latar belakang dan rumusan masalah, maka penelitian ini untuk menguji dan menganalisis pengaruh fasilitas terhadap tingkat pendapatan hotel melalui studi mengenai pengaruh fasilitas terhadap keputusan tamu untuk menginap di Nyiur Indah Beach Hotel Pangandaran.

Manfaat penclitian ini adalah untuk mengetahui sejauhmana fasilitas yang dimiliki Nyiur Indah Beach hotel dapat menarik kunjungan tamu dan meningkatkan pendapatan hotel. 


\section{B. KAJIAN PUSTAKA}

\section{Pendapatan}

Menurut tim pcnyusun Ilcatan Akuntansi Indonesia dalam bukunya Standar Akuntansi Keuangan melalui PSAK No. 23, mcnjelaskan pengertian pendapatan sebagai berikut, "Pendapatan adalah arus masuk bruto dari manfaat ekonomi yang timbul dari aktivitas normal perusahaan selama suatu periode bila ants masuk itu mengakibatkan kenaikan ekuitas, yang tidak berasal dari kontribusi penanaman modal". (2002:232). Scdangkan menurut Ibrahim (2001: 377) mendefinisikan pengertian pendapatan (Revenue) yaitu pendapatan yang diperoleh pentsahaan sebagai basil penjualan barang atau jasa dalam bentuk uang tunai, wesel tagih atau piutang. Pendapatan yang diperoleh dari aktiva tetap, penerbitan surat-surat berharga, hasil pinjaman tidak termasuk kategori pendapatan".

Berdasarkan dari beberapa pengertian pendapatan diatas, maka dapat disimpulkan bahwa pendapatan merupakan suatu penghasilan ants masuk bruto yang didapat dari penjualan barang atau jasa selama suatu periode tertentu. Pendapatan diakui bila besar kemungkinan manfaat ekonomi sehubungan dengan transaksi tersebut diperoleh perusahaan. Biasanya perusahaan perlu mcmpunyai sistem angaran dan pelaporan keuangan intern yang efektif, perusahaan tersebut menelaah dan bila perlu merevisi estimasi pendapatan sewaktujasa diberikan.

Menurut Abdullah Assegaf Ibrahim dalam bukunya Dictionmy Of Accounting (Kamus Akuntansi) (2001:378) menerangkan pengakuan pendapatan adalah sebagai berikut: "Pendapatan adalah aliran arus masuk harta-harta (aktiva) yang timbul dari penyerahan barang atau jasa yang dilakukan olch suatu unit usaha selama suatu periode tertentu dan merupakan suatu proses yang berjalan secara tents menerus dengan demikian untuk tujuan pelaporan keuangan dianggap perlu untuk menentukan saat pendapatan diakui". Pengakuan pendapatan dengan acuan pada tingkat penyelesaian dari suatu transaksi sering disebut sebagai metode persentase penyelesaian. Menurut metode ini pendapatan diakui dalam periode akuntansi pada saat jasa diberikan. Pengakuan pendapatan atas dasar ini memberikan informasi yang berguna mengenai tingkat kegiatan jasa dan kinerja dari suatu perusahaan dalam suatu periode.

\section{Fasilitas}

Menurut Sulastiyono (2006) fasilitas adalah perlengkapan-perlengkapan fisik untuk memberikan kemudahan kepada para tamu dalam melaksanakan aktivitas- aktivitas atau kegiatan-kegiatannya, sehingga kebutuhan-kebutuhan tamu dapat terpenithi selama tinggal dihotel. Segala fasilitas yang ada yaitu kondisi fasilitas, kelengkapan, desain interior dan eksterior serta kebersihan fasilitas harus diperhatikan tenttama yang bcrkaitan dengan apayang dirasakan atau konsumen secara langsung. Pelanggan memang harus dipuaskan, sebab kalau tidak puas mereka akan meninggalkan perusahaan dan menjadi pclanggan pesaing. Hal ini dapat menyebabkan penurunan penjualan dan pada gilirannya akan menurunkan laba.

Fasilitas-fasilitas dalam suatu hotel (sulastiyono, 2006) adalah kamar tidur dengan segala perlengkapannya, restoran/caffe dengan pendukungnya, fasilitas - tambahan (fasilitas olahrag,a atau hiburan), dan lain-lain. Fasilitas adalah sarana yang disediakan olch holcl.Pada dasarnya fasilitas ini merupakan faktor yang menentukan pilihan orang untuk tinggal atau menginap disuatu hotel tertentu.

\section{Keputusan Menginap}

Menurut Setiadi (2003:413) Pengambilan keputusan konsumen adalah proses pengintegrasian yang mengkombinasikan pengetahuan untuk mengevaluasi dua atau lebih perilaku alternatif, dan memilih salah satu diantaranya. 
Keputusan konsumen merupakan salah satu bagian yang terdapat di dalam perilaku konsumen. Swastha (2003:9) mengungkapkan bahwa perilaku konsumen adalah tindakan-tindakan individu, kelompok atau organisasi yang berhubungan dengan proses pengambilan kcputusan dalam mendapatkan barang-barang atau jasa ekonomis yang dapat dipengaruhi oleh lingkungan. Karena keputusan membeli dapat dipengaruhi oleh lingkungan, maka perushaan haruslah mampu memanfaatkan hal tersebut.

Keputusan pembelian merupakan kegiatan individu yang secara langsung terlibat dalam pengambilan keputusan untuk melakukan pembelian terhadap produk yang ditawarkan oleh penjual. Pengertian keputusan pembelian, menurut Kotler \& Armstrong (2001: 226) adalah tahap dalam proses pengambilan keputusan pembeli di mana konsumen benar-benar membeli. Pengambilan keputusan merupakan suatu kegiatan individu yang secara langsung terlibat dalam mendapatkan dan mempergunakan barang yang ditawarkan. -

Ada tiga aktivitas yang berlangsung dalam proses keputusan pembelian olehkonsumen yaitu (Hahn, 2002:69) :

a. Rutinitas konsumen dalam melakukan pembelian.

b. Kualitas yang diperoleh dari suatu keputusan pembelian.

c. Komitmen atau loyalitas konsumen yang sudah biasa beli dengan produk pesaing.

Proses pengambilan keputusan pembelian seorang calon konsumen banyak dipengaruhi oleh perilaku konsumen. Menurut Kotler (2005:202) faktor-faktor yang mempengaruhi perilaku konsumen tersebut dijelaskan sebagai berikut:

a. Faktor budaya memiliki pengaruh yang terluas dan terdalam dalam perilaku konsumen. Pemasar perlu memahami peranan yang dimainkan oleh budaya, sub budaya, dan kolas sosial pembeli. Budaya adalah serangkaian nilai, persepsi, keinginan dan perilaku dasar yang dipelajari oleh anggota masyarakat dari keluarga dan instansi penting lain. Sub budaya adalah kelompok orang yang memiliki sistem lain yang sama berdasarkan pengalaman dan situasi kehidupan yang serupa. Kelas sosial adalah pembagian kelompok masyarakat yang relatif permanen dan relatif teratur dimana anggota-anggotanya memiliki nilai, minat dan perilaku yang serupa.

b. Perilaku konsumen juga dipengaruhi oleh faktor sosial, seperti kelompok kecil, keluarga, peran sosial, dan status yang melingkupi konsumen tersebut. Kelompok adalah dua atau lebih sekelompok orang yang berinteraksi untuk memenuhi tujuan individu atau tujuan bersama. Keluarga merupakan oerganisasi pembelian di masyarakat tempat konsumen berada yang paling penting, dan keluarga telah diteliti secara luas. Peran terdiri atas jumlah aktifitas yang diharapkan untuk dilakukan menurut orang-orang di sekitarnya.

c. Keputusan seorang pembeli juga dipengaruhi oleh karakteristik seperti umur dan tahap siklus hidup, pekei jaan, situasi ekonomi, biaya hidup, kepribadian, dan konsep Scpanjang hidupnya orang akan mengubah barang dan jasa yang dibelinya.

d. Pilihan pembclian dipengaruhi empat faktor psikologi utama: motivasi, persepsi, pembelajaran, serta kepercayaan dan sikap. Motivasi adalah kebutuhan yang mendorong scseorang secara kuat mencari ataskeputudan tersebut. Persepsi adalah menyeleksi, mengatur, dan menginterpretasikan informasi guna membentuk gambaran yang berarti untuk dunia. Pembelajaran adalah perubahan perilaku seseorang karena pengalaman. Keyakinan adalah pemikiran deskriptif yang dipertahankan sescorang mengenai sesuatu. Sikap adalah evaluasi, perasaan, dan kecenderungan yang konsisten atau suka atau tidak sukanya seseorang terhadap objek atau ide.

Pemasar dapat memasukkan sesuatu ke dalam pikiran konsumen, mengubah sikap konsumen atau membuat keputusan bertindak. Untuk hal itu, menurut kotler (2002:713) maka akan digunakan model AIDA, yaitu :

a. Attention, timbulnya perhatian konsumen terhadap suatu pemasaran yang dilakukan produsen. 
b. Interest, rnunculnya rasa ketertarikan terhadap objek yang ditawarkan produsen tersebut atau membangkitkan minat.

c. Desire, setelah rasa tertarik, timbul hasrat atau keinginan untuk memiliki objek tersebut.

d. Action, tindakan konsumen pembelian yang dilakukan konsumen setelah memiliki hasrat atau keinginan untuk memiliki objek.

Titik tolak untuk memahami perilaku pembeli adalah model rangsangan tanggapan. Rangsangan pemasaran dan lingkumgan mulai memasuki kesadaran pcngambilan keputusan menimbulkan keputusan pembelian tertentu pembeli. Karakteristik pembcli dan proses.

\section{Pendapatan Hotel dari Tingkat Sewa Kamar}

Tingkat pendapatan sewa kamar hotel dalam hal ini dapat dinilai dari besarnya jurnlah tamu yang menginap dengan berbagai fasilitas yang diberikan oleh hotel tersebut. Menin;kat apabila suatu hotel telah dilengkapi dengan berbagai fasilitas dan pelayanan yang diberikan dengan balk sehingga akan memuaskan para tamu yang berkunjung dan akan menarik minat pengunjung untuk kembali lagi ke Hotel tersebut, maka akan menambah pendapatan hotel tersebut. Seperti dikemukakan oleh Sami Ridjal D dan Kealany HD dalam kutipan bukunya Peluang di Bidang Pariwisata (2003:65), mencrangkan bahwa, pendapatan hotel merupakan pendapatan yang diterima dari penyewaan kamar hotel".

Dari kutipan diatas dapat disimpulkan bahwa pendapatan penyewaan kamar merupakan pendapatan yang paling utama menurut kebanyakan Hotel di Indonesia. Pada dasarnya kualitas pelayanan jasa berupaya pada pemenuhan kebutuhan dan keinginan para tamu serta ketetapan penyampaian untuk mengimbangi harapan pelanggan, misalnya kualitas dan pelayanan pada tingkat huni kamar hotel yang berakibat pada tinggi rendahnya penyewaan kamar hotel bagi para tamu, yang akan mengakibatkan naik turunnya pendapatan yang diperoleh hotel.

\section{METODE PENELITIAN}

Sesuai dengan tujuan yang ingin dicapai, maka jenis penelitian yang digunakan adalah deskriptif dan verifikatif. Penelitian deskriptif merupakan penelitian yang bertujuan untuk memperoleh deskripsi tentang ciri-ciri variabel penelitian, yaitu fasilitas dan keputusan untuk menginap Sedangkan penelitian verifikatif pada dasarnya ingin menguji kebenaran dari suatu hipotesis yang dilaksanakan melalui pengumpulan data di lapangan (Arikunto, 1996:9).

\section{Operasionalisasi Variabel}

\section{Variabel independen}

Variabel yang mempengaruhi variabel yang lain atau disebut variabel bebas, dalam penelitian ini yang menjadi variabel bebas adalah fasilitas (X). Fasilitas merupakan segala sesuatu yang memudahkan konsumen dalam menggunakan jasa perusahaan tersebut. Indikator dari variabel ini adalah:

Tabel 3. Variabel Fasilitas

\begin{tabular}{|c|l|}
\hline No & \multicolumn{1}{|c|}{ FASILITAS } \\
\hline 1 & Kamar yang nyaman, bersih dan rapi untuk dipakai. \\
\hline 2 & Fasilitas lobi yang nyaman. \\
\hline 3 & Akses Internet \\
\hline 4 & Tersedianya tempat parkir yang menyenangkan. \\
\hline 5 & Tersedia Lift untuk tamu \\
\hline
\end{tabular}




\section{Variabel dependen}

Variabel yang dipengaruhi oleh variabel lain atau variabel yang menjadi akibat bagi variabel lain, dalam penelitian ini yang menjadi variabel dependen adalah keputusan untuk menginap (Y). Keputusan untuk menginap dapat didefinisikan sebagai pendapatan hotel yang bersumber dari produk dan jasa yang dijual kepada tamu tindakan konsumen untuk memakai jasa Hotel Nyiur indah beach atas dasar kecocokan dan kepuasan dari apa yang dicari dan dibutuhkan. Indikator dari variabel ini yaitu:

Tabel 4. Variabel Keputusan Untuk Menginap

\begin{tabular}{|c|l|}
\hline No & \multicolumn{1}{|c|}{ KEPUTUSAN UNTUK MENGINAP } \\
\hline 1 & Tamu Mendapatkan skala prioritas \\
\hline 2 & Pelayanan Prima \\
\hline 3 & Fasilitas sesuaian dengan kebutuhan. \\
\hline
\end{tabular}

Populasi dalam penelitian ini adalah pengunjung Nyiur Indah Beach Hotel di Pangandaran yang memakai fasilitas dan jasa hotel tersebut. Teknik pengambilan sampel yang digunakan adalah dengan non probability sampling yaitu teknik yang tidak memberikan kesempatan sama bagi setiap unsur atau anggota populasi untuk dijadikan sampel. Sedangkan penentuan pengambilan jumlah responden (sampel) dilakukan melalui teknik accidental sampling (sampel kebetulan), yaitu siapa saja yang secara kebetulan bertemu dengan peneliti dapat digunakan sebagai sampel (Sugiyono, 2007). Pengambilan data dilakukan pada saat konsumen menginap di Hotel Nyiur Pangandaran.

Pcnentuan jumlah minimal sampel dihitung berdasarkan rumus sebagai berikut (Ferdinand, 2006):

$\mathrm{n}=(5 \mathrm{x}$ jumlah indicator yang digunakan $)=5 \times 10$ indikator

$=50$ sampel

Dari hasil perhitungan rumus di atas dapat diperoleh jumlah sampel yang akan diteliti adalah sebesar 80 responden.

Metode pengumpulan data yang digunakan disini meliputi tiga macam yaitu: Wawancara

Wawancara adalah pengumpulan data dengan mengadakan tanya jawab dengan responden, yaitu dengan daftar pertanyaan untuk diisi dengan keterangan-keterangan oleh responden selama proses wawancara.

Kuesioner

Kuesioner atau daftar pertanyaan merupakan teknik pengumpulan data yang dilakukan dengan cara menyusun pertanyaan-pertanyaan yang sifatnya tertutup dan terbuka dengan jawaban yang telah disediakan, dan harus diisi oleh responden dengan cara memilih salah satu alternatifjawaban yang tersedia.

Studi kepustakaan

Merupakan pengumpulan data dengan tujuan untuk mengetahui berbagai pengetahuan atau teori yang berhubungan dengan penelitian, diantaranya berasal dari buku, jurnal ataupun berbagai literatur yang relevan.

Analisis regresi linier berganda digunakan untuk mengetahui seberapa besar pengaruh variabel bebas yaitu: Fasilitas $(\mathrm{X})$ terhadap tingkat pendapatan $(\mathrm{Y})$. Adapun bentuk persamaan regresi linier berganda yang digunakan dalam penelitian ini sebagai berikut:

$$
Y=a+b X
$$


Keterangan:

$\mathrm{Y}=\quad$ Tingkat Pendapatan

$\mathrm{a}=\quad$ Konstanta

$\mathrm{b}=\quad$ Koefisien regresi

Berdasarkan basil dari model analisis yang digunakan dalam penelitian ini, maka dapat digunakan sebagai dasar dalam menganalisa untuk membuktikan hipotesis- hipotesis yang diajukan. Pembuktian hipotesis tersebut dapat dilakukan dengan menggunakan uji statistik yaitu uji $\mathrm{F}$ (Uji serempak) dan uji T (Uji parsial). Uji T dilakukan untuk mencari makna hubungan variabel $\mathrm{X}$ terhadap Y sedangkan uji $\mathrm{F}$ dilakukan untuk mengetahui apakah model persamaan regresi yang diajukan dapat diterima atau ditolak.

\section{HASIL DAN ANALISIS}

Uji validitas digunakan untuk mengukur sah atau tidaknya suatu kuesioner. Suatu kuesioner dikatakan valid jika pernyataan pada kuesioner mampu untuk mengungkapkan sesuatu yang akan diukur oleh kuesioner tersebut. Uji validitas dihitung dengan membandingkan nilai r hitung (correlated item-total correlations) dengan nilai $r$ tabel.Jika $r$ hitung > dari $r$ tabel (pada taraf signifikasi 5\%) maka pernyataan tersebut dinyatakan valid.

Tabel 5. Uji Validitas

\begin{tabular}{|c|c|c|c|c|}
\hline \multirow{5}{*}{ Variabel } & Item & $\begin{array}{c}\text { Person correlation (R } \\
\text { hitung) }\end{array}$ & R tabel & Ket. \\
\hline \multirow{5}{*}{ Fasilitas (X) } & $\mathrm{X} 1$ & 0,744 & 0.219 & VALID \\
\cline { 2 - 5 } & $\mathrm{X} 2$ & 0,747 & 0.219 & VALID \\
\cline { 2 - 5 } & $\mathrm{X} 3$ & 0,804 & 0.219 & VALID \\
\cline { 2 - 5 } & $\mathrm{X} 4$ & 0,684 & 0.219 & VALID \\
\cline { 2 - 5 } & $\mathrm{X} 5$ & 0,738 & 0.219 & VALID \\
\cline { 2 - 5 } & $\mathrm{N} 7$ & $0 \mathrm{R} 19$ & 0.219 & VA1m \\
\hline $\begin{array}{c}\text { Keputusan } \\
\text { Untuk } \\
\text { Menginap } \\
\text { (Y) }\end{array}$ & $\mathrm{Y} 1$ & 0,794 & 0.219 & VALID \\
\cline { 2 - 5 } & $\mathrm{Y} 2$ & 0,862 & 0.219 & VALID \\
\cline { 2 - 5 } & $\mathrm{Y} 3$ & 0,777 & 0.219 & VALID \\
\hline
\end{tabular}

Sumber: Data Primer diolah SPSS, 2015

Dari basil diatas menunjukkan bahwa nilai dari $r$ hitting lebih besar dibandingkan dengan nilai $r$ tabel, berarti untuk uji kualitas data yang ditunjukkan dari uji validitas bahwa variabel fasilitas dan keputusan menginap adalah valid. Uji reliabilitas dilakukan dengan melihat basil perhitungan nilai CronbachAlpha (a). Suatu variabel dikatakan reliabel jika memberikan nilai Cronbach Alpha (a) > 0,6 yaitu bila penelitian ulang dengan waktu dan variabel yang berbeda akan menghasilkan kesimpulan yang sama. Tetapi sebaliknya bila alpha $<0,6$ maka dianggap kurang handal, artinya bila variabel tersebut dilakukan penelitian ulang dengan waktu dan variabel yang berbeda akan menghasilkan kesimpulan yang berbeda.

Tabel 6. Uji Realibilitas

\begin{tabular}{|c|c|c|c|}
\hline Variahel & $\begin{array}{c}\text { Cronbach } \\
\text { Alpha }\end{array}$ & $\begin{array}{c}\text { Standar } \\
\text { Reliabilitas }\end{array}$ & Ket. \\
\hline Fasilita> (X) & 0,731 & 0.60 & Reliabel \\
\hline Kcputusan Untuk Mcnginap (Y) & 0,765 & 0.60 & Reliabel \\
\hline
\end{tabular}

Sumber: Data Primer SPSS, 2015

102 | Jurnal Kepariwisataan: Destinasi, Hospitalitas dan Perjalanan, Volume 2 Nomor 2, 2018: 95-108 
Dari basil yang diperoleh setelah uji reliabilitas menunjukkan bahwa, untuk variabcl fasilitas dan tingkat pendapatan hotel bisa di uji selanjutnya atau seluruh variabel menunjukkan nilai yang reliabel.

Analisis deskriptif jawaban responden tentang variabel fasilitas didasarkan pada jawaban responden atas pernyataan-pernyataan seperti terdapat dalam kuesioner yang disebarkan kepada responden. Variasi jawaban responden untuk variabel Fasilitas, dimana SS (Sangat Setuju), S (Setuju), RR (Ragu- ragu), TS (Tidak Setuju), dan STS (Sangat Tidak Setuju) dapat dilihat pada tabel berikut:

Tabel 7. Frekuensi Jawaban Variabel Fasilitas

\begin{tabular}{|c|c|c|c|c|c|c|c|}
\hline No & Pertanyaan & SS & S & $\mathrm{RR}$ & TS & STS & Jml \\
\hline I & $\begin{array}{c}\text { Kamar yang } \\
\text { nyaman, bersih } \\
\text { dan rapi untuk } \\
\text { dipakai. }\end{array}$ & $\begin{array}{c}28 \\
56 \%\end{array}$ & $\begin{array}{c}22 \\
44 \%\end{array}$ & $\begin{array}{c}0 \\
0 \%\end{array}$ & $\begin{array}{r}0 \\
0 \%\end{array}$ & $\begin{array}{c}0 \\
0 \%\end{array}$ & $\begin{array}{c}50 \\
100 \%\end{array}$ \\
\hline 2 & $\begin{array}{c}\text { Fasilitas lobi yang } \\
\text { nyaman }\end{array}$ & $\begin{array}{c}21 \\
-12 \%\end{array}$ & $\begin{array}{c}29 \\
58 \%\end{array}$ & $\begin{array}{c}0 \\
0 \%\end{array}$ & $\begin{array}{c}0 \\
0 \%\end{array}$ & $\begin{array}{c}0 \\
0 \%\end{array}$ & $\begin{array}{c}50 \\
100 \%\end{array}$ \\
\hline 3 & Ak;cs lntcrnet & $\begin{array}{c}24 \\
48 \%\end{array}$ & $\begin{array}{c}26 \\
52 \%\end{array}$ & $\begin{array}{c}0 \\
0 \%\end{array}$ & $\begin{array}{c}0 \\
0 \%\end{array}$ & $\begin{array}{c}\mathrm{U} \\
0 \%\end{array}$ & $\begin{array}{c}50 \\
100 \%\end{array}$ \\
\hline 4 & $\begin{array}{c}\text { Tersedianya } \\
\text { parkir yang aman }\end{array}$ & $\begin{array}{c}24 \\
48 \%\end{array}$ & $\begin{array}{c}26 \\
52 \%\end{array}$ & $\begin{array}{c}0 \\
0 \%\end{array}$ & $\begin{array}{c}0 \\
0 \%\end{array}$ & $\begin{array}{c}0 \\
0 \%\end{array}$ & $\begin{array}{c}50 \\
100 \%\end{array}$ \\
\hline 5 & $\begin{array}{l}\text { Tersedia Lift } \\
\text { untuk tamu }\end{array}$ & $\begin{array}{c}41 \\
82 \%\end{array}$ & $\begin{array}{c}9 \\
18 \%\end{array}$ & $\begin{array}{c}0 \\
0 \%\end{array}$ & $\begin{array}{c}0 \\
0 \%\end{array}$ & $\begin{array}{c}0 \\
0 \%\end{array}$ & $\begin{array}{c}50 \\
100 \%\end{array}$ \\
\hline 6 & $\begin{array}{l}\text { Tersedianya } \\
\text { Resturan }\end{array}$ & $\begin{array}{c}\text { II } \\
22 \%\end{array}$ & $\begin{array}{r}33 \\
0 \\
660 \\
\end{array}$ & $\begin{array}{c}\stackrel{6}{\sim} ; \\
1 \sim \quad-0\end{array}$ & $\begin{array}{c}\mathrm{ll} \\
0 \% 0 \%\end{array}$ & 0 & $\begin{array}{r}50 \\
0 \\
100 \% \\
\end{array}$ \\
\hline 7 & $\begin{array}{c}\text { Tersedianya } \\
\text { Jasa } \\
\text { Laundry }\end{array}$ & $\begin{array}{c}7 \\
14 \%\end{array}$ & $\begin{array}{c}29 \\
58 \%\end{array}$ & $\begin{array}{c}14 \\
28 \%\end{array}$ & $\begin{array}{c}0 \\
0 \%\end{array}$ & $\begin{array}{c}0 \\
0 \%\end{array}$ & $\begin{array}{c}50 \\
100 \%\end{array}$ \\
\hline
\end{tabular}

Sumber: Data Primer SPSS, 2015

a. Berdasarkan Tabel mengenai kamar hotel Nyiur Indah bersih dan nyaman, responden yang menyatakan Sangat Setuju sebanyak 28 orang atau 56\%. Setuju sebanyak 22 orang atau 44\%, raguragu sebanyak 0 orang atau $0 \%$, tidak setuju sebanyak 0 orang atau $0 \%$ dan sangat tidak sctuju 0 orang atau $0 \%$. Hasil diatas menunjukkan bahwa mayoritas responden menyatakan sangat setuju bahwa kamar hotel Nyiur Indah bersih dan nyaman.

b. Berdasarkan Tabel mengenai tersedia lobi yang nyaman untuk tempat menunggu tamu, responden yang menyatakan Sangat Setuju sebanyak 21 orang atau 42\%, Setuju sebanyak 29 orang atau 58\%, ragu-ragu sebanyak 0 orang atau $0 \%$ dan tidak setuju sebanyak 0 orang atau $0 \%$. Hasil diatas menunjukkan bahwa mayoritas responden menyatakan setuju bahwa tersedia lobi yang nyaman untuk tempat menunggu tamu.

c. Berdasarkan Tabel mengenai fasilitas akses internet, responden yang menyatakan Sangat Setuju sebanyak 24 orang atau $48 \%$, Setuju sebanyak 26 orang atau $52 \%$, ragu-ragu sebanyak 0 orang atau $0 \%$, tidak setuju sebanyak 0 orang atau $0 \%$ dan sangat tidak setuju 0 orang atau $0 \%$. Hasil diatas menunjukkan bahwa mayoritas responden menyatakan setuju bahwa tersedia Akses Internet. 
d. Berdasarkan label mengenai fasilitas Tersedianya tempat parkir yang aman, responden yang menyatakan Sangat Setuju sebanyak 24 orang atau 48\%, Setuju sebanyak 26 orang atau 52\%, raguragu sebanyak 0 orang atau $0 \%$, tidak setuju sebanyak 0 orang atau $0 \%$ dan sangat tidak setuju 0 orang atau $0 \%$. Hasil diatas menunjukkan bahwa mayoritas responden menyatakan setuju bahwa Tersedianya tempat parkir yang aman.

e. Berdasarkan Tabel mengenai fasilitas Tersedianya lift untuk tamu, responden yang menyatakan Sangat Setuju sebanyak 41 orang atau $82 \%$, Setuju sebanyak 9 orang atau $18 \%$, ragu-ragu sebanyak 0 orang atau $0 \%$, tidak setuju sebanyak 0 orang at au $0 \%$ dan sangat tidak setuju 0 orang atau $0 \%$. Hasil diatas menunjukkan bahwa mayoritas responden menyatakan sangat setuju bahwa Tersedianya lift untuk tamu.

f. Berdasarkan Tabel mengenai fasilitas Tersedianya restoran, responden yang menyatakan Sangat Setuju sebanyak 11 orang atau 22\%, Setuju sebanyak 33 orang atau 66\%, ragu-ragu sebanyak 6 orang atau $12 \%$, tidak setuju sebanyak 0 orang atau $0 \%$ dan sangat tidak setuju 0 orang atau $0 \%$. Hasil diatas menunjukkan bahwa mayoritas responden menyatakan setuju bahwa Tersedianya restoran.

g. Berdasarkan Tabel mengenai fasilitas jasa laundry, responden yang menyatakan Sangat Setuju sebanyak 7 orang atau 14\%, Setuju sebanyak 29 orang atau 58\%, ragu-ragu sebanyak 14 orang atau $28 \%$, tidak setuju sebanyak 0 orang atau $0 \%$ dan sangat tidak setuju 0 orang atau $0 \%$. Hasil diatas menunjukkan bahwa mayoritas responden menyatakan setuju bahwa Tersedianya jasa laundry.

\section{Variabel Keputusan Menginap}

Analisis dcskriptif jawaban responden tentang variabel keputusan menginap didasarkan pada jawaban responden atas pernyataan-pernyataan seperti terdapat dalam kuesioner yang disebarkan kepada responden. Variasi jawaban respondcn untuk variabel Keputusan Tamu untuk Menginap dimana SS (Sangat Setuju), S (Setuju), RR (Ragu-ragu), TS (Tidak Setuju), dan STS (Sangat Tidak Setuju) dapat dilihat pada tabel berikut:

Tabel 8. Frekuensi Jawaban Variabel Keputusan Tamu Menginap

\begin{tabular}{|c|c|c|c|c|c|c|c|}
\hline No. & Pertanyaan & SS & S & $\mathrm{RR}$ & TS & STS & Jml \\
\hline \multirow[t]{2}{*}{1} & Tamu Mendapatkan & 32 & 18 & 0 & 0 & 0 & 50 \\
\hline & skala prioritas & $64 \%$ & $36 \%$ & $0 \%$ & $0 \%$ & $0 \%$ & $100 \%$ \\
\hline \multirow[t]{3}{*}{2} & Pelayanan Prima & & & 0 & 0 & 0 & 50 \\
\hline & & $\begin{array}{c}34 \\
6 \mathrm{~S}^{\circ} \mathrm{ra}\end{array}$ & & $0 \%$ & $0 \%$ & $0 \%$ & $100 \%$ \\
\hline & & & $32 \%$ & & & & \\
\hline \multirow[t]{3}{*}{3} & Fasilitas sesuaian & & 21 & 0 & 0 & 0 & 50 \\
\hline & deng & & & $0 \%$ & $0 \%$ & $0 \%$ & $100 \%$ \\
\hline & & $58 \%$ & & & & & \\
\hline
\end{tabular}

a. Berdasarkan Tabel 8 mengenai Tamu rnendapatkan skala prioritas, responden yang menyatakan Sangat Setuju sebanyak 32 orang atau 64\%, Setuju sebanyak 18 orang atau $36 \%$, ragu-ragu sebanyak 0 orang atau $0 \%$, tidak setuju sebanyak 0 orang atau $0 \%$ dan sangat tidal( setuju sebanyak 0 orang 
atau 0\%. Hasil diatas menunjukkan bahwa mayoritas responden menyatakan mendapatkan pelayanan prioritas sehingga tamu memutuskan untuk menginap.

b. Berdasarkan Tabel 8 mengenai pelayanan prima, responden yang menyatakan Sangat Setuju sebanyak 34 orang atau $68 \%$, Setuju sebanyak 16 orang atau $32 \%$, ragu-ragu sebanyak 0 orang atau $0 \%$, tidak setuju sebanyak 0 orang atau $0 \%$ dan sangat tidak setuju sebanyak 0 orang atau $0 \%$. Hasil diatas menunjukkan bahwa mayoritas responden menyatakan bahwa tamu rnendapatkan pelayanan prima schingga tamu memutuskan untuk menginap.

c. Berdasarkan Tabel 8 men-4enai Fasilitas sesuaian dengan kebutuhan, responden yang menyatakan Sangat Setuju sebanyak 29 orang atau 58\%, Setuju sebanyak 21 orang atau $42 \%$, ragu-ragu scbanyak 0 orang atau $0 \%$, tidak setuju sebanyak 0 orang atau $0 \%$ dan sangat tidak setuju sebanyak 0 orang atau $0 \%$. Hasil diatas menunjukkan bahwa mayoritas responden menyatakan bahwa Fasilitas yang tersedia di Hotel Nyiur Indah sudah sesuai dengan kebutuhan tamu.

\section{Uji Hipotesis}

Analisis data dilakukan dengan menggunakan regresi linear berganda dengan tujuan untuk mengetahui pengaruh fasilitas terhadap keputusan tamu untuk menginap. Statistical Package For Social Science (SPSS) akan digunakan untuk membantu proses analisis linear berganda.

\section{Koefisien Determinasi}

Koeifisien determinasi digunakan dalam mendeteksi seberapa jauh hubungan dan kemampuan model dalam menjelaskan variasi dependen. Pada data yang diolah terdapat tiga variabel independen. Seperti pada tabel berikut ini:

Tabel 9. Model Summar

\begin{tabular}{|c|c|c|c|c|}
\hline Model & $\mathrm{R}$ & $\mathrm{R}$ Square & $\begin{array}{c}\text { Adjusted } \\
\text { R Square }\end{array}$ & $\begin{array}{c}\text { Std. Error of the } \\
\text { Estimate }\end{array}$ \\
\hline 1 &, $697 \mathrm{a}$ &, 486 &, 466 & 1,555 \\
\hline
\end{tabular}

a.Predictors: (Constant), $\mathrm{x}$

Pada tabel di atas terlihat bahwa angka R 0,697, maka hubungan antara variabel dependen terhadap variabel independen adalah positif dan kuat. Hal itu disebabkan karena angka R harus lebih bcsar sarna dengan 0,6 dan mendekati angka 1 . Selanjutnya dilihat pada R Square yaitu 0,486, menunjukkan bahwa fasilitas dengan variabel keputusan tam untuk menginap sebesar $48,6 \%$ dan sisanya $51,4 \%$ dapat dijelaskan diluar dari variabel penelitian.

\section{Uji F (Uji Simultan)}

Uji F digunakan untuk menguji apakah variabel independen secara scrempak berpengaruh signifikan terhadap variabel dependen. Dimana F hitung > F tabel, maka hipotesis diterima atau secara bersama-sama variabel bebas dapat menerangkan variabel terikatnya secara serentak. Sebaliknya apabila F hitung < F tabel, maka HO diterima atau secara bersama-sama variabel bebas tidak memiliki pengaruh terhadap variabel terikat.

Untuk mengetahui signifikan atau tidak pengaruh secara bersama-sama variabel bebas terhadap variabel terikat maka digunakan probability sebesar $5 \%(a=0,005)$. 
Tabel 10 ANOVAb

\begin{tabular}{|l|r|r|r|r|l|}
\hline Model & $\begin{array}{r}\text { Sum of } \\
\text { Square }\end{array}$ & df & Mean Square & F & Sig. \\
\hline 1 & 174,108 & 1 & 58,036 & 23,987 &, $000 \mathrm{a}$ \\
$\begin{array}{l}\text { Regression } \\
\text { Residual } \\
\text { Total }\end{array}$ & 353,880 & 76 & 2,419 & & \\
& & 79 & & & \\
\hline
\end{tabular}

a. Predictors: (Constant), s

b. Dependent Variable: y

Berdasarkan uji anova atau uji f dari output SPSS, terlihat bahwa diperoleh $\mathrm{f}$ hitung sebesar 23,987dan probabilitas sebesar 0,000. Secara lebih tepat, nilai F hitung dibandinakan dengan F tabel dimana jika $\mathrm{F}$ hitung $>\mathrm{F}$ tabel maka secara simultan variabel independen berpengaruh positif dan signifikan terhadap variabel dependen. Pada taraf a $=(0,05)$ dengan derajat kebebasan pembilang/dfl $(\mathrm{k})$ = 1 (jumlah variabel independen) dan derajat kebebasan penyebut/df2, diperoleh nilai $\mathrm{F}$ tabel 2,72. Melihat nilai F hitung 23,987 lebih besar dari nilai F tabel (2,72). Dengan demikian, dari basil pengujian diatas bahwa $\mathrm{F}$ hitung lebih besar dari $\mathrm{F}$ tabel maka variabel independen berpengaruh positif dan signifikaan terhadap variabel dependen.

\section{Uji T}

Uji t digunakan untuk mengetahui pengaruh masing-masing indikator dari variabel bebas terhadap variabel terikat. Uji $\mathrm{t}$ dilakukan dengan membandingkan antara t-hitung dengan $\mathrm{t}$-tabel. Untuk menentukan nilai t-tabel, maka ditentukan dengan tingkat signifikansi $5 \%$ dengan derajat kebebasan $\mathrm{df}=$ (n-k-1) dimana $\mathrm{n}$ adalah jumlah responden dan $\mathrm{k}$ adalah jumlah indikator/variabel.

Tabel 11 Coefficients ${ }^{a}$

\begin{tabular}{|c|c|c|c|c|c|}
\hline \multirow[t]{2}{*}{ Model } & \multicolumn{2}{|c|}{$\begin{array}{l}\text { Unstandardized } \\
\text { Coefficients }\end{array}$} & \multirow{2}{*}{$\begin{array}{l}\text { Standardize } \\
\text { d } \\
\text { Coefficients } \\
\text { Beta }\end{array}$} & \multirow[b]{2}{*}{$\mathrm{t}$} & \multirow[b]{2}{*}{ sig. } \\
\hline & B & Std. & & & \\
\hline & 95 & 1,529 & & ,627 &, 533 \\
\hline (Constant)x & $\begin{array}{l}, 46 \\
7\end{array}$ & ,098 & ,452 & 4,784 & 000, \\
\hline
\end{tabular}

a. Dependent Variable: y

Sumber: Data Primer SPSS, 2015

Untuk nilai thitung sebesar 4,784 dan untuk nilai t tabel dari hasil n-k-1 (n=responden, $\mathrm{k}=$ =variabel independen) sebesar 1,665. Dengan begitu bahwa untuk nilai t hitung 4,784 > nilai t tabel 1,665 maka fasilitas berpengaruh positif.

Jika nilai Sig»ifikan $<0,05$ berarti berpengaruh signifikan. Pengujian pengaruh fasilitas terhadap keputusan tamu untuk menginap diperoleh nilai signifikansi sebesar 0,000 . Oleh karena besarnya nilai 
signifikansi $<0,05$ maka dapat disimpulkan bahwa variabel fasilitas berpengaruh positif dan signifikan. Maka dalam pengujian ini hipotesis di terima.

Dengan demikian berdasarkan uji t (uji parsial) di atas, variabel fasilitas (X) adalah variabel yang paling dominan berpengaruh terhadap keputusan menginap.

\section{Variabel Fasilitas Terhadap Keputusan Menginap}

Dari hasil tersebut diatas, menunjukkan bahwa pada saat pengujian kualitas data semua pertanyaan yang ada pada kuesioner dikatakan valid dengan ketentuan melebihi nilai $r$ tabel yang ditnatia nilai $r$ tabel sebesar 0,219. Dan untuk nilai reabilitas didapat nilai sebesar 0,731 dengan ketentuan di atas 0,60 dapat dikatakan kuesioner yang ada dinyatakan reabel untuk pengujian selanjutnya.

Untuk nilai thitung sebesar 4,784 clan untuk nilai t tabel dari hasil n-k-1 (n-responden, k=variabel independen) sebesar 1,665. Dengan begitu bahwa untuk nilai t hitung 4,784 > nilai t tabel 1,665 maka fasilitas berpengaruh positif.

Jika nilai Signijikan $<0,05$ berarti berpengaruh signifikan. Pengujian pcngaruh fasilitas terhadap keputusan menginap diperoleh nilai signifikansi sebesar 0,000. Oleh karena besarnya nilai signifikansi < 0,05 maka dapat disimpulkan bahwa variabel fasilitas berpengaruh positif dan signifikan. Maka dalam pengujian ini hipotesis di terima. Jadi dalam penelitian ini, dapat di justifikasi bahwa variabel fasilitas yang mempunyai pengaruh dan signifikan terhadap keputusan menginap hams mendapat perhatian dari pimpinan hotel Nyiur Indah Beach Pangandaran. Dilihat dari tabel uji $\mathrm{T}$ bahwa fasilitas paling dominan dalam memberikan pengaruh terhadap keputusan menginap.

\section{Analisis Tingkat Pendapatan dari Perspektif Fasilitas}

Tingkat pendapatan sewa kamar hotel dalam hal ini dapat dinilai dari besarnya jumlah tamu yang menginap dengan berbagai fasilitas yang diberikan oleh hotel tersebut. Meningkat apabila suatu hotel telah dilengkapi dengan berbagai fasilitas dan pelayanan yang diberikan dengan baik sehingga akan memuaskan para tamu yang berkunjung dan akan menarik minat pengunjung untuk kembali lagi ke Hotel tersebut, maka akan menambah pendapatan hotel tersebut. Seperti dikemukakan oleh Sami Ridjal D dan Kealany HD dalam kutipan bukunya Peluang di Bidang Pariwisata, menerangkan bahwa: "Pendapatan Hotel merupakan pendapatan yang diterima dari penyewaan kamar hotel".

Dari hasil pembahasan diketahui bahwa fasilitas hotel sangat berpengaruh terhadap keputusan menginap. Hal ini sesuai dengan hasil wawancara dengan GM Nyiur Indah Beach Hotel pada tanggal 9 Mei 2015 yang menyatakan bahwa "para tamu akan sangat nyaman ketika mengetahui bahw kami mempunyai fasilitas hotel yang lengkap dan disertai dengan pelayanan yang prima sehingga tamu merasa terfasilitasi dan terlayani dengan baik". Dari pernyataan tersebut dapat di artikan ketika fasilitas baik fisik maupun non fisik tersebut dapat memberikan kepuasan bagi tamu sesuai dengan keinginan tamu tentunya tamu tersebut akan memutuskan untuk menginap di hotel yang bersangkutan.

Dan ketika banyak tamu yang menginap tentunya akan berdampak pada tingkat pendapatan hotel yang bersangkutan. Dan pada kontek penelitian ini yaitu Nyiur Indah Beach Hotel Pangandaran dengan memberikan fasilitas yang sesuai dengan kebutuhan tamu Nyiur Indah Hotel Pangandaran telah dapat mensiasati sisi pendapatan hotel dengan memberikan layanan fasilitas yang memang menjadi daya tank bagi tamu.

\section{E. SIMPULAN}

Berdasarkan hasil penelitian dan hasil analisis data, dapat ditarik kesimpulan sebagai berikut: Terdapat pengaruh secara positif dan signifikan dari variabel fasilitas terhadap variabel keputusan 
menginap. Hal ini didasarkan pada analisis kuantitatif, Dengan begitu bahwa untuk nilai t hitung 4,784 > nilai t tabel 1,665 maka fasilitas berpengaruh positif terhadap keputusan menginap.

Dari hasil pembahasan ditemukan kamar yang bersih dan nyaman merupakan faktor yang dominan dari fasilitas. Setiap room boy yang bekerja di hotel Nyiur Indah Pangandaran hams memastikan bahwa kamar yang akan ditempati tamu hams benar-benar bersih dan tertata rapi. Jika terdapat perabot kamar yang rusak hendaknya segera diperbaiki agar tidak mengganggu kenyamanan para tamu pada saat menempati kamar tersebut.

Penelitian ini dilakukan pada hotel bintang tiga mungkin hasil dari penelitian ini akan berbeda jika dilakukan pada hotel lain yang berada pada level diatas atau dibawahnya. Ketiga variabel diatas dapat memiliki pengaruh yang lebih tinggi jika diterapkan pada hotel bintang lima, karena pangsa pasar mereka adalah kelas atas yang menganggap fasilitas merupakan alasan mutlak mereka mencari tempat penginapan. Namun sebaliknya jika diterapkan pada hotel kelas melati, variabel ini akan memiliki pengaruh yang lebih kecil. Yang tentunya memiliki kemampuan ekonomi yang lebih terbatas, sehingga mereka lebih cenderung terpengaruh dengan tarif dari pada kualitas pelayanan dan fasilitas.

\section{DAFTAR REFERENSI}

Drs. Danang Sunyoto, SH., SE., MM. 2012, Dasar-dasar ManajemenPemasaran. Penerbit: CAPS, Yogyakarta.

Husnul Khatimah, 2011, "Analisis Pengaruh Kualitas Pelayanan Terhadap Kepuasan Nasabah", (Studi pada nasabah BRI Cabang Semarang Pattimura).

Kotler, Philip, 2005, "Manajemen Pemasaran". Jilid I, Jakarta: Indeks , 2005, "Manajemen Pemasaran". Jilid 11, Jakarta: Indeks.

Kotler, Phillip. 2007. Manajemen Pemasaran,jilid ledisi ke duabelas. Jakarta: PT. Indeks. ,2007. Manajemen Pemasaran,jilid 2cdisi ke duabelas. Jakarta: PT Indeks. Lupiyohadi, Rambat, 2001, "Manajemen pemasaran jasa teori dan praktik", Salemba Empat, Jakarta.

Lupiyoadi, Rambat \& A Hamdani, 2006. "Manajemen Pemasaran Jasa". Salemba Empat, Jakarta

Ratih Hardiyanti, 2010, "Analisis Pengaruh Kualitas Pelayanan Terhadap Kepuasan Konsumen Menggunakan Jasa Penginapan (villa) Agrowisata Kebun Teh Pagilaran".

Rambat Lupiyoda, A. Hamdani, 2006, Manajemen Pemasaran jasa, edisi kedua, Penerbit: Salemba Empat, Jakarta.

Sulastiyono, Agus, 2006. "Manajemen Penyelenggaraan Hotel". Bandung; Alfabeta

Swasta, Basu, 2009," Azas-Azas Marketing", Yogyakarta: Liberty. Tjiptono, Fandy, 2004," Manajemen Jasa", Andy Offset, Yogyakarta. Internet:

http://anditriplea.blogspot.com/2011/05/perkembangan-hotel-bisnis.html. (Diakses 2 Mei 2015)

http://www.bisnis.corn/hotel-di-makassar-menjamur-phri-harapkan-tak-ada-lagi- izinbaru. (Diakses 2 Mei 2015)

http://id.shvoong.corn/business-management/management/2186428-pengertian-atau-definisihotel/. (Diakses 7 Mei 2015) 